\title{
Social capital and entrepreneurial behaviour advancing innovativeness in interaction between small rural entrepreneurs and researchers: A phenomenographic study
}

\author{
Sari livonen ${ }^{a}$, Paula Kyrö ${ }^{b}$, Sinikka Mynttinen ${ }^{b}$, Marjo Särkkä-Tirkkonena ${ }^{c}$ and Helena Kahiluoto ${ }^{c}$ \\ anniversity of Helsinki, Ruralia-institute, sari.iivonen@helsinki.fi, marjo.sarkka-tirkkonen@helsinki.fi \\ ${ }^{b}$ Aalto University School of Economics, Small Business Center, paula.kyro@hse.fi, sinikka.mynttinen@pyk.hkkk.fi \\ ${ }^{c}$ MTT Agrifood Research Finland, helena.kahiluoto@mtt.fi
}

\begin{abstract}
Innovation processes between entrepreneurs and researchers are activated by interaction. Social capital increases the efficiency of action, for example, information dissemination by minimizing redundancy. To learn more about how to build and develop social capital assumes that we understand how entrepreneurs behave and what their expectations of interaction with researchers are. In this study we adopt a theoretical approach that combines social capital and entrepreneurial behaviour. The firms in this study are located in the South-Savo region of Finland and operate in food production. As a result of interviews with 15 entrepreneurs a system of categories was compiled as the phenomenographic method assumes. It became obvious that the key dynamics of the cooperation between entrepreneurs and researchers is embedded in a common understanding of entrepreneurial behaviour and learning as well as a trust-building process. As a practical implication we could further suggest that researchers are expected to modify their behaviour to the specific features of entrepreneurial behaviour in order to pave the way to enhance innovativeness of rural entrepreneurs.
\end{abstract}

Keywords: small business, food production, research cooperation, entrepreneurial behaviour, social capital

\section{Introduction}

Local food production has attracted attention in recent years. However, the modest capacity and innovation capabilities of small players in a globally competed market have proved problematic. More intense cooperation between research and development units could promote the learning and knowledge exchange essential to the future innovation potential of small firms operating in food production. However, according to a Nordic study, cooperation with research units has had an insignificant role in the innovation activities of farms or firms refining food (Niemi and Virkkala, 2005).

Innovation processes are stimulated by interactions and depend on a player's ability to cooperate and interact. Thus to improve cooperation and interactive learning between entrepreneurs and researchers requires a better understanding of the factors with bearing on it. Burt (1992) argues that social capital increases the efficiency of action, for example, information dissemination by minimizing redundancy. Thus, understanding the dynamics might serve to advance the collaboration between entrepreneurs and researchers. Researchers have paid attention to the influence of social capital not only on the development of human capital (Coleman, 1988) but also on the economic performance of firms (Bourdieu, 1986; Baker, 1990) and rural society (Svendsen and Svendsen, 2004). To define social capital Nahapiet and Ghoshal (1998) combine the conceptualizations of Baker (1990), Bourdieu (1986, 1993) and Putnam (1995) as follows: "Social capital is the sum of the actual and potential resources embedded within, available through, and derived from the network of relationships possessed by an individual or social unit".

Nahapiet and Ghoshal (1998) have identified three dimensions of social capital: structural, relational and cognitive dimensions. To develop social capital in interaction between entrepreneurs and researchers highlights the need for a relational dimension. This refers to the personal relationships people have developed with each other through a history of interactions (Granovetter, 1992). Among the key facets are trust and trustworthiness (Fukuyama, 1995; Putnam, 1993), norms and sanctions 
(Putnam, 1995), likewise obligations and expectations (Burt, 1992; Coleman, 1990; Granovetter, 1985). In the process of developing trust predictability is perceived to be important. Ellingsen (2006) found that the different ways of creating predictability are related to different kinds of trust. She identified three interrelated forms as the social foundation of trust, namely precontractual trust, structural trust, and relational trust.

Precontractual trust is the taken-for-granted, implicit trust which is a social link between the individual and society, a precondition for cooperation in general. It presupposes some degree of homogeneity, including a common cultural, meaning and knowledge base. According to Ellingsen and Lotherington (2008), stereotypes about gender and gender roles are part of the elements in the social basis for precontractual trust. Structural trust, which is based on formal structures and positions, is necessary in order to generalise, to deduce from the known to the unknown, to enter into long-term relations and to trust the unknown. Relational trust refers to proximity, acquaintance, and cooperation. It is based on experiences and knowledge of the other (Zucker, 1983). Relational trust is developed not only through cooperation and communication processes, but can also be based on family ties, kinship, ethnicity, religion or subculture. Thus, a reputation for trustworthiness is formed through an individual's own and others' experiences. Finally, relational trust may be based on reputation mediated through a medium or mediator, who creates the necessary feeling of proximity. (Ellingsen and Lotherington, 2008) Thus to reduce uncertainties through trust building could be a key factor in advancing collaboration between entrepreneurs and researchers. Therefore to better understand its dynamics could indeed help to improve the innovativeness of small rural businesses.

To learn more about how to build and develop social capital assumes that we understand how entrepreneurs and small business owners behave and what their expectations of interaction with researchers are. Therefore, in order to understand entrepreneurial behaviour, the focus should be on the performance of the entrepreneur (Sarasvathy, 2008). In this study we adopt as loose theoretical lenses an approach that combines social capital and entrepreneurial behaviour. We are interested in what entrepreneurs want and expect from interaction, how they act and perceive the scope of social capital in interaction to increase innovativeness of their business.

\section{Methodology}

\section{A conceptual consideration of phenomenography}

To investigate how entrepreneurs perceive and experience the collaboration between researchers in developing their innovation capacity we adopt phenomenography as our research method. It "aims to find and systematise different forms of thought in terms of which people interpret aspects of reality - aspects which are socially significant and which are at least supposed to be shared by the members of a particular kind of society" (Marton, 1981). The focus is on what is experienced and conceptualised. It involves both the content and the process of producing it and is deeply embedded in the context. Marton introduces the concepts of first and second order perspective. While the first order perspective aims at describing various aspects of the world, the second order perspective aims at describing people's experience of various aspects of the world and for our study it helps us to understand how entrepreneurs perceive their action and interaction with researchers. The totality of such categories of description denotes a kind of collective intellect, a structured pool of ideas, conceptions and beliefs underlying the possible interpretation of (possible) constructions of reality (Marton, 1981). "Most often the purpose of phenomenographic analysis is pointed out to be the development of categories of description for the different ways in which a thing has been shown to be understood, with these then being expected denoting a collective mind" (Marton, 1995). Thus this method is highly suitable for our research purpose.

The system of categories per se can be, and often is, presented as the results of phenomenographic research. However, its harshest critics have addressed its inability to advise how to form these categories. According to Hasselgren and Beach (1996), this requires reading the material as a hermeneutic circle. Then, we have "piles" of data, each of which is said to depict something unique 
about the phenomenon. These are examined with two rules, internal consistency, related to the referential and structural aspects and parsimony, referring to the minimum number of categories explaining the variations in the data. This forms the system of categories. Little has been said about the role of existing theories in this process. Here we have adopted the interplay between social capital and entrepreneurial behaviour as an approach, a loose frame or lens to investigate how entrepreneurs experience the collaboration between researchers.

\section{Sample description}

To capture as diverse experiences as possible 15 food production entrepreneurs representing different lines in food sector businesses in the region of South Savo were chosen. South Savo is a typical rural area in the eastern part of Finland where primary production is the main branch in the food sector. Nine of the firms were micro size (less than 9 employees), which is typical for the area. Three of the firms use seasonal workers. The age of the companies varied between 0 and 46 years, the personnel numbered between 1 and 35 and the ages of the entrepreneurs were in the categories 25-44 $(\mathrm{N}=7), 45-54(\mathrm{~N}=3), 55-64(\mathrm{~N}=4)$ and $>64(\mathrm{~N}=1)$ years. Five of the cases had a turnover between 100,000 and $290,000 € /$ year, three between 300,000 and 499,000/year, one between 500,000 and $799,000 € /$ year, one between 800,000 and $999,000 € /$ year, three more than 1,000,000 $€$ /year and two less than $99,000 € /$ year. Regarding educational background, four of the entrepreneurs had basic comprehensive education or incomplete higher education and eleven an agricultural qualification or university degree. One of the entrepreneurs had a qualification in the food sector. Thus each of them had their specifics, but together they represented the diverse aspects and contexts of the food industry in South Savo. Their specifics were assumed to give as different and diverse experiences as possible.

The data consisted of their interviews, which were guided by the following themes; motives for cooperation, experiences and expectations of cooperation, initiation of cooperation with developers or researchers and co-operation with developers or researchers as a process. The interviews were conducted in the period April - August 2009 by three researchers. The average length of an interview was 56 minutes, range from 37 minutes to 78 minutes. Before the actual interviews the interview procedure was piloted in order to check the validity of the themes and to learn how to guide the interview process. The categorisation proceeded in several phases. First the research team of five members representing the diverse aspects of local food production and its business specifics read the written interviews then compiled coherent stories of each interview to identify the differences, but also the similarities of how the entrepreneurs experienced their collaboration with researchers. In the third phase the interviews were coded in NVivo 7 qualitative data analysis software (QSR NVivo 7.0.281.0 SP4, 2007) and each interview was analysed separately to capture its uniqueness. Finally, after several iteration rounds in the researcher team, the system of categories with internal consistency and parsimony was identified and compiled.

\section{Results}

Two shared categories were indentified in the transcribed interviews and their coherent stories. These were also validated by the coding process. The first concerned entrepreneurial learning and the second entrepreneurial behaviour. These were mainstreaming principles throughout the cooperation process with researchers. 


\section{Entrepreneurial learning}

Entrepreneurs' experiences of the dynamics of learning followed similar paths. More than collective actions entrepreneurs seek interaction between individuals, be they entrepreneurs or researchers. All the entrepreneurs preferred informal problem-oriented learning by doing in a real life context. This is also reflected in their expectations regarding ways of conducting research cooperation. The entrepreneurs seemed to appreciate personal advice from professionals with practical skills. Examples of these expressions of entrepreneurs are presented in Table 1.

Table 1. Examples of expressions of the dynamics of learning.

\begin{tabular}{|c|c|}
\hline Case & Learning \\
\hline 1 & $\begin{array}{l}\text { "I have learned more here in life than anywhere at school.", "I have got real life, concrete benefit and new } \\
\text { models of action" }\end{array}$ \\
\hline 2 & $\begin{array}{l}\text { "I might be ok in school, but to get it ready as a product to be sold to the customer that is, like this real } \\
\text { action...", "now if something should be developed, could somebody come and concretely face-to-face } \\
\text { together hands in fat, to be outright ..." }\end{array}$ \\
\hline 3 & "When we were involved in these processes, we automatically gained understanding." \\
\hline 4 & $\begin{array}{l}\text { "this quality thing where actually almost only our herbs were investigated, a lot of samples and tests were } \\
\text { run, a lot was done here...", } \\
\text { "they should be ready and able to personally advise the company" }\end{array}$ \\
\hline 5 & $\begin{array}{l}\text { "when we started we were trained hands-on to produce these products and we got this kind of support in al } \\
\text { those activities needed for producing juice", "it was concrete teaching and very practical" }\end{array}$ \\
\hline 6 & $\begin{array}{l}\text { "they send us students for work life training periods and then we exchange experiences and get advice, we } \\
\text { borrow equipment and in that direction we have quite good cooperation" }\end{array}$ \\
\hline 7 & "I am myself quite a good product developer, I have the skill always there, and I use it as I walk." \\
\hline 8 & "Learning is discussing and trying." \\
\hline 9 & $\begin{array}{l}\text { "In the programmes of this research institution...we spend days and nights on the fields" } \\
\text { "In summertime the visits of researchers to farms are important." }\end{array}$ \\
\hline 10 & $\begin{array}{l}\text { "It is important to realise one's own skills and the level of action." , "...the information in research projects } \\
\text { should be adjusted to the current situation of the firm, make the propositions for", "improvements... so that } \\
\text { the research would not be left on the shelf" }\end{array}$ \\
\hline 11 & $\begin{array}{l}\text { "in the apple project we delivered different apples, which were baked and tested for cakes in the test } \\
\text { kitchen", "through experience we found out which subspecies were suitable for it when fresh and also with } \\
\text { frozen berries, that was fine" }\end{array}$ \\
\hline 12 & "...and we tested them many times with N., those mixture proportions" \\
\hline 13 & $\begin{array}{l}\text { "Every time we do it in practise we get the best results." } \\
\text { "Definitely this is the right way... so that we can get the specialists here." }\end{array}$ \\
\hline 14 & "A project should be developed benefits all the parties." \\
\hline 15 & "We had developed the products. We are going to make a test now in the autumn." \\
\hline
\end{tabular}

\section{Entrepreneurial behaviour}

Another mainstreaming category concerned entrepreneurial behaviour. It became obvious that all the entrepreneurs described their ideas through action; why, what and how they did things. Thus action was the mainstreaming idea of experiencing reality. As Sarasvathy (2008) argues, entrepreneurs begin by asking who they are, what they know and whom they know, and immediately start taking action and interacting with other people. They focus on what they can do and do it. Table 2 summarises examples of this dynamics. However, more than asking who they were, they were interested in finding solutions to the problems in hand, that is, what they needed to know. Entrepreneurs like to use the telephone to talk personally to potential sources of needed knowledge or even to hold face-to-face discussions when knowledge is needed. They are actors and initiators in this process. Considering the ways and circumstances in which information and knowledge are exchanged between different regional actors it is easy to conclude that knowledge exchange is an entrepreneur-led or initiated action process based on an immediate need to know or need to solve the problem or situation. Knowledge is sought until some solution to the problem can be found. What became obvious was the tendency to find individuals who might have information on and solutions to the problem at hand. (Table 2) 
Table 2. Entrepreneurial behaviour

\begin{tabular}{|c|c|c|}
\hline Case & Whom I know & I do, I am the initiator, affordable risk \\
\hline 1 & $\begin{array}{l}\text { "We really got a lot of facts from them" } \\
\text { "It was a most rewarding discussion" } \\
\text { "We have used relatives and acquaintances quite a } \\
\text { lot" }\end{array}$ & $\begin{array}{l}\text { "they readily tell when we ask" } \\
\text { "if something occurs to me, I take the phone and call ... that } \\
\text { is how somebody always knows somebody else.. ask } \\
\text { him/her I am sure he/she will tell you" }\end{array}$ \\
\hline 2 & $\begin{array}{l}\text { "so I asked if she could raise pigs for us" } \\
\text { "I call N.N he knows I am sure" }\end{array}$ & $\begin{array}{l}\text { "I am totally clumsy reading the newspapers and Internet } \\
\text {..." }\end{array}$ \\
\hline 3 & $\begin{array}{l}\text { "yes at a moment there is a guy N.N. in X with whom } \\
\text { we have quite open discussions" }\end{array}$ & $\begin{array}{l}\text { "the reason was that I myself was active there" } \\
\text { "when we had got acquainted then we talked and came up } \\
\text { with ideas, and then it took shape" }\end{array}$ \\
\hline 4 & $\begin{array}{l}\text { "when we were in the process I called N,N, more } \\
\text { than once a week or vice versa" }\end{array}$ & $\begin{array}{l}\text { "On most of these projects of course the initiator has been } \\
\text { the Agrifood Research Centre or a university or some other } \\
\text { organisation" (projects with failure experiences) }\end{array}$ \\
\hline 5 & $\begin{array}{l}\text { "I called the university" } \\
\text { "we always face some problem or question, we } \\
\text { approach University or some other body" }\end{array}$ & $\begin{array}{l}\text { "we were the initiators and made contact and then got the } \\
\text { help we needed " } \\
\text { "many times we have called, made direct contact" }\end{array}$ \\
\hline 6 & $\begin{array}{l}\text { "there might have been a long period with no } \\
\text { contact whatsoever, but when the need arises, I am } \\
\text { sure it pops into my mind that is how it was, they } \\
\text { are able to handle this kind of thing" }\end{array}$ & $\begin{array}{l}\text { "...if I need I take it. So simple." } \\
\text { "when I say call and ask, she sends a text message or } \\
\text { email... it means that s/he then might read it only } \\
\text { tomorrow, even if it was needed now ..." }\end{array}$ \\
\hline 7 & $\begin{array}{l}\text { "we have arranged this Saimaa Wood Network for } \\
\text { marketing and logistics." } \\
\text { "Then it was the Lappish man, the director, who } \\
\text { called..." }\end{array}$ & $\begin{array}{l}\text { "...we have taken care of it ourselves" } \\
\text { "some good things, which are now here... one has to do } \\
\text { them oneself..." } \\
\text { "One can't afford to leave problems unsolved." }\end{array}$ \\
\hline 8 & "When I have needed help, I have called..." & $\begin{array}{l}\text { "There are things which can't be done by others...then we } \\
\text { have to do them" }\end{array}$ \\
\hline 9 & $\begin{array}{l}\text { "At times I bombard her/him, even if there is no } \\
\text { project ..." }\end{array}$ & "It depends on the farmer, how things work." \\
\hline 10 & $\begin{array}{l}\text { "We went to N.N. to have a talk... to tell him what } \\
\text { we had in mind..." }\end{array}$ & "We have to search for new partners" \\
\hline 11 & "I try to find out the collaborator." & $\begin{array}{l}\text { "One has to look out for oneself, if there are such things, } \\
\text { that one can participate... that is suitable for our business." }\end{array}$ \\
\hline 12 & "We checked it in the office of food products." & $\begin{array}{l}\text { "There have been problems, but one has to pull oneself } \\
\text { together and think how to do and what to do, very } \\
\text { carefully." }\end{array}$ \\
\hline 13 & $\begin{array}{l}\text { "And they are such people whom we call every now } \\
\text { and then" } \\
\text { "I can always call and ask... }\end{array}$ & $\begin{array}{l}\text { "In it we were allowed to form the content ourselves" } \\
\text { "...if only I could call to many people, I would get the help, } \\
\text { eventually" }\end{array}$ \\
\hline 14 & $\begin{array}{l}\text { "We have given the subject to the researchers: this } \\
\text { should be examined." }\end{array}$ & $\begin{array}{l}\text { "The entrepreneur must have the capability to pick out } \\
\text { those things from the research which are needed" } \\
\text { "Quick decisions and other things must be done by the } \\
\text { entrepreneur himself." }\end{array}$ \\
\hline 15 & $\begin{array}{l}\text { "I have been in cooperation with the Technical } \\
\text { Research Centre of Finland..." } \\
\text { "We have got access to all the stores in the region." }\end{array}$ & $\begin{array}{l}\text { "...but if our own know-how is not enough, the only way is } \\
\text { to find outside help and in that case we have to commit } \\
\text { ourselves, too." }\end{array}$ \\
\hline
\end{tabular}

\section{Scope of social capital in interaction}

In identifying the role of social capital in the interaction of entrepreneurs and researchers cognitive dimensions in the cooperation as well as the trust of the entrepreneurs in the researchers or developers emerged from the data. The shared understanding of the goal in cooperation can be achieved in different ways. It may be based on personal relations (Cases 3, 12), professional skills of researchers/developers in practice (Cases $7,13,15)$ and discussions clarifying the goal to both sides (Cases 12, 14). In general, entrepreneurs expect that the goal of the research cooperation is made clear enough to both sides and the demands of the practice should be considered in it. The entrepreneurial behaviour and way to learn are highlighted in the past experiences and the expectations of the entrepreneurs as to how to cooperate with the researchers. (Table 3 ) 
Table 3. Examples of entrepreneurs' expressions of shared understanding of the goal in research cooperation.

\begin{tabular}{ll}
\hline Case & Past experiences and expectations of entrepreneurs \\
\hline 1 & "I had a feeling that this would continue successfully" \\
& "the language used should be a little bit more commonplace" \\
\hline 3 & "we understood each other because we were acquaintances" \\
& "shared understanding can be achieved by discussions" \\
\hline 4 & "We have understood each other quite well." \\
\hline 7 & "There have not been big problems in the communication between us" \\
& "The biggest problem is to get the researchers understand the scale of production. A design product differs \\
& "It is not necessary to speak the same language. It is necessary to understand what is being talked about." \\
\hline 8 & "I am always extremely busy. But when I visit the research institute, I have a feeling that there is no hurry." \\
\hline 9 & "We have understood each other.", "Research topics should be farmer-initiated." \\
\hline 10 & "Entrepreneurs may feel they are in a lower position in contact with more highly educated researchers \\
which affects the communication between entrepreneurs and researchers."
\end{tabular}

Structural and especially relational trust emerged strongly from the data. Experiences of structural trust are based on an image of researchers and research units as objective producers of knowledge valuable to entrepreneurs. Relational trust may be familiarity born of cooperation (Cases 3, 8, 9, 13) and positive experiences of the professional skills of the researcher (Cases 9, 15). A reputation for trustworthiness can be also formed through another entrepreneur's positive experiences (Case 1). The entrepreneurs also had experiences of mistrust, mostly relational mistrust, which had arisen from the suspicion of the leaking of confidential information by researchers $($ Cases $7,8,12$ ) or unfair treatment by researchers (Cases 2,14$)$. (Table 4 )

Table 4. Examples of entrepreneurs' expressions on precontractural, structural and relational trust/mistrust in research collaboration.

\begin{tabular}{|c|c|}
\hline Trust & Mistrust \\
\hline Precontractual & Precontractual \\
\hline $\begin{array}{l}\text { 10. "One shouldn't put much faith in what politicians } \\
\text { and bank managers say...but the researchers are much } \\
\text { more trustworthy..." }\end{array}$ & $\begin{array}{l}\text { 3."I could have became suspicious of if the title of } \\
\text { researcher had been underlined" }\end{array}$ \\
\hline Structural & Structural \\
\hline $\begin{array}{l}\text { 5. "We have the confidence, that through this we'll get } \\
\text { valuable knowledge about the berries and what they } \\
\text { have inside them." } \\
6 \text {. "An uncommitted researcher may be more trustful } \\
\text { in circumstances where business is involved" } \\
\text { 9. "The researchers are trustworthy and this feeling is } \\
\text { based on the expectation that they have knowledge" }\end{array}$ & $\begin{array}{l}\text { 14. "I have a sceptical view that these projects are } \\
\text { justified a lot with the projects themselves, and then the } \\
\text { target to aim for is missing." }\end{array}$ \\
\hline Relational & Relational \\
\hline $\begin{array}{l}\text { 1. "Other farmers recommended cooperation with the } \\
\text { research unit” }\end{array}$ & $\begin{array}{l}\text { 2. "So that our issue is no more insignificant than ... } \\
\text { someone else's..." }\end{array}$ \\
\hline $\begin{array}{l}\text { 3. "We have known each other for a long time...we are } \\
\text { acquaintances from the earlier projects." } \\
\text { 8. "projects start and finish but people stay, it is } \\
\text { trustful" }\end{array}$ & $\begin{array}{l}\text { 7. "they had called me from some papers that you have } \\
\text { developed this kind of a product in cooperation with the } \\
\text { polytechnic, although it was not so. This has also, I'm } \\
\text { afraid, happened, but it doesn't create confidence..." }\end{array}$ \\
\hline $\begin{array}{l}\text { 9. "I think that in that project they have in the field a } \\
\text { clear picture of what it is" }\end{array}$ & $\begin{array}{l}\text { 8. "for me it was quite a shock as I was in an event } \\
\text { presenting our product and there was another blueberry }\end{array}$ \\
\hline 13. "such organizations and actors with whom we have & muesli. And we had the same product developer..." \\
\hline
\end{tabular}


been for years...we readily continue that way 15. "We have said several times that this is confidential and the researchers do understand it"
12. "that to give it to some others, which I have paid for, let's say that it has been tested and it is a finished product. And I at once thought, here, is this kind of copying. It should not be that way. Then I felt that the trust disappears then..."

14. "We did not fund the research project and after that the behaviour of researcher towards us has changed. It is a shame."

\section{System of categories in research co-operation}

Now, when the system of categories is compiled of how entrepreneurs experience and concepttualise the collaboration between researchers or developers in developing their innovativeness takes shape. The key dynamics of the cooperation process between entrepreneurs and researchers as an opportunity to add value to the business is embedded in the social capital, more detailed in the formation of shared understanding of the goal and trust-building. These processes are mainstreamed by two shared categories: entrepreneurial learning and entrepreneurial behaviour. As long as a researcher/developer can adopt entrepreneurial learning and entrepreneurial behaviour in the function and has practical skills enough, this promotes the formation of relational trust and probably also the exploitation of the results in business. Figure 1 presents the system and its dynamics.

Entrepreneurial behaviour: what I need, who I know, how to

act

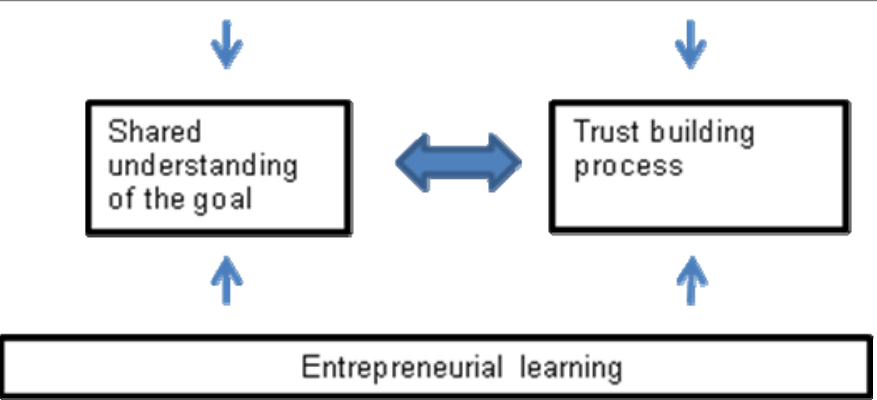

Figure 1. The system of categories.

\section{Discussion and conclusions}

Based on the entrepreneurs' varying experiences and perceptions of the collaboration with researchers our conception of factors affecting the research collaboration became clearer and enables research organizations to develop their way of operating with entrepreneurs. The building of shared goals and trust between members arose from the data as key facets of social capital in cooperation process. To share goals with entrepreneurs entails understanding motives and entrepreneurial behaviour. Inkpen and Tsang (2005) argue that cultural conflicts will arise if certain partners push forward their own ways of doing things. This may also be true in research collaboration with entrepreneurs. In order to avoid conflicts in research cooperation entrepreneurial learning should be considered in the process. According our data it is obvious that entrepreneurs prefer informal problem-oriented learning by doing in a real life context which is also reflected to their expectations regarding ways to conduct research cooperation. Trust plays an important role in the willingness of actors to share knowledge (Dyer and Singh, 1998). In this study, the importance of relational trust was perceived most often as the form of trust showing a high regard for personal relations among entrepreneurs.

According to Fromhold-Eisebith (2004) the networks of innovative milieu are typically activated for a certain project, whereas social capital involves a continuous and regular maintenance of community relationships. Relational trust is often developed over time through repeated interactions. Offering opportunities for relational trust building is a challenging task for research organizations often having 
a high turnover of research personnel. Because trust in a social network may also be transitive and members can trust in the trust of others (Svendsen and Svendsen, 2004), trust-building is the task which everyone working in research and development process with entrepreneurs must become conscious of. It would be also important to understand how and in which circumstances an accumulated relational trust in research personnel can be converted to structural trust in research unit. Therefore, building structural trust through relational trust is an issue which needs further research. Our study shows that in research cooperation entrepreneurs' relational trust in researchers can be based partly on their professional skills in practice, which supports the idea that cognitive capital can be converted into relational capital (Liao and Welsch, 2005).

We argue that as long as researchers and institutions can understand entrepreneurial needs and behaviour and are also able to provide positive experiences, trustful relations and concrete results in this kind of learning processes they can enhance innovativeness. How can the interaction between researchers and entrepreneurs be improved to increase the innovativeness of small food companies? The answer reverts to our original suggestion that all innovation processes depend on the players' ability to cooperate and interact. In this case it means that researchers should improve their abilities to learn and to adjust their activities to entrepreneurial behaviour. They need to adopt an entrepreneurial learning approach in order to provide positive experiences that increase trust in collaboration.

Acknowledgements: This study is a part of the Explorative Partnership in Research (EXPRES) project which is funded by the European Social Fund (ESF).

\section{References}

Baker, W. (1990) Market networks and corporate behavior. American Journal of Sociology 96: 589-625.

Bourdieu, P. (1986) The forms of capital. In: J.G. Richardson (ed.) Handbook of theory and research for the sociology of education. New York: Greenwood, pp. 241-258.

Bourdieu, P. (1993) Sociology in question. London: Sage.

Burt, R.S. (1992) Structural holes: The social structure of competition. Cambridge, MA: Harvard University Press.

Coleman, J.S. (1988) Social capital in the creation of human capital. American Journal of Sociology 94: S95-S120.

Dyer, J.H. and H. Singh (1998) The relational view: Cooperative strategy and sources of interorganizational competitive advantage. Academy of Management Review 23: 660679.

Ellingsen, M. (2006) Searching the invisible - An exploration of trust and change in late modernity. Doctoral dissertation in progress. University of Troms $\varnothing$.

Ellingsen, M. and A.T. Lotheringron (2008) Network credit: The magic of trust. In: I. Aaltio,P. Kyrö and E. Sundin (eds.) Women entrepreneurship and social capital. A dialogue and construction. Copenhagen Business School Press, pp. 121-146.

Fromhold-Eisebith, M. (2004) Innovative milieu and social capital - complementary or redundant concepts of collaboration-based regional development. European Planning Studies 12(6): 747-765.

Fukuyama, F. (1995) Trust: Social virtues and the creation of prosperity. London: Hamish Hamilton.

Granovetter, M.S. (1992) Problems of explanation in economic sociology. In: N. Nohria and R. Eccles (eds.) Networks and organizations: Structure, form and action. Boston: Harvard Business School Press, pp. 2556

Hasselgren, B. and D. Beach (1996) Phenomenography a "good-for-nothing brother" of phenomenology? Report No. 1996:05. Dept. of Educational Research. Sweden: Gothenberg University.

Inkpen, A.C. and E.W.K. Tsang (2005) Social capital, networks and knowledge transfer. Academy of Management Review 30(1):03637425

$9^{\text {th }}$ European IFSA Symposium, 4-7 July 2010, Vienna (Austria) 
Lesser, E.L. (2000) “Leverating social capital in organizations”. In: E.L. Lesser (ed.) Knowledge and social capital: Foundations and applications, pp. 3-16.

Liao, J. and H. Welsch (2005) Roles of social capital in venture creation: key dimensions and research implications. Journal of small business management 43(4):345-362.

Marton, F. (1981) Cognosco ergo sum. Reflections on reflections. Nordisk Pedagogik 15:165-180.

Marton, F. (1995) Phenomenography - Describing conceptions of the world around us. Instructional Science 10:177-200.

Nahapiet, J. and S. Ghoshal (1998) Social capital, intellectual capital and the organizational advantage. Academy of Management Review 23 (2): 242-266.

Niemi, K. and S. Virkkala (2005) Yritysten innovaatiotoiminta elintarvike- ja matkailualoilla Keski-Pohjanmaalla ja elektroniikka-alalla Oulun Eteläisessä. Pohjoismaisen tutkimushankkeen tuloksia. Chydeniusinstituutin selvityksiä 2/2005.

Putnam, R.D. (1993) The prosperous community: Social capital and public life. American Prospect 13: 35-42.

Putnam, R.D. (1995) Bowling alone: America's declining social capital. Journal of Democracy 6: 65-78.

Sarasvathy, S.D. (2008) Effectuation: Elements on entrepreneurial expertise. Edward Elgar.

Sarasvathy, S.D., N. Dew, S.R. Velamuri and S. Venkataraman (2003) Three views of entrepreneurial opportunity. In: Acs, Z. and D. Audretsch (eds) Handbook of Entrepreneurship Research. Kluwer Academic Publishers, Dordrecht, pp. 141-160.

Svendsen, G.L.H. and G.T. Svendsen (2004) The creation and destruction of social capital. Entrepreneurship, cooperative movements and institutions. Cheltenham: Edward Elgar.

Zucker, L.G. (1986) Production of trust: Institutional sources of economic structure 1840-1920. Research in Organizational Behaviour 8: 53-111. 